Research Article

\title{
Effect of Freezing-Thawing Cycle on the Mechanical Properties and Micromechanism of Red Mud-Calcium-Based Composite Cemented Soil
}

\author{
Hao Wen (D), Chongxian Suo, Yafen Hao, Peige Fan, and Xiaoqiang Dong $(\mathbb{D}$ \\ College of Civil Engineering, Taiyuan University of Technology, Taiyuan 030024, China \\ Correspondence should be addressed to Xiaoqiang Dong; dongxiaoqiang@tyut.edu.cn
}

Received 10 August 2020; Revised 28 September 2020; Accepted 20 October 2020; Published 30 November 2020

Academic Editor: Qiang Tang

Copyright (c) 2020 Hao Wen et al. This is an open access article distributed under the Creative Commons Attribution License, which permits unrestricted use, distribution, and reproduction in any medium, provided the original work is properly cited.

\begin{abstract}
The environmental issues caused by solid waste have become increasingly serious. Adding additive is considered as an effective measure to improve the performance of the cemented soil. Therefore, the feasibility study of solid waste such as red mud and desulfurization gypsum used in composite cemented soil is in urgent demand. In this study, the mechanical properties and durability to freezing-thawing cycle of red mud-calcium-based composite cemented soil (RMCC) were analyzed through compressive strength test, resistivity test, and freezing-thawing cycle test. The action mechanism of RMCC was revealed through a series of X-ray diffraction (XRD) and scanning electron microscope (SEM) with energy dispersive spectrometer (EDS) test. The results show that the optimal red mud content in RMCC is $12 \%$. As the freezing-thawing cycle progresses, the difference in resistivity and pressure sensitivity of RMCC gradually weakens. When the freezing-thawing cycle reaches 7 , the pressure sensitivity characteristic of RMCC is lost. The change in resistivity and pressure sensitivity can be used to characterize the damage caused by the freezing-thawing cycle. Combined with XRD and SEM analysis, the presence of minerals such as $\mathrm{K}_{2} \mathrm{Ca}_{5}\left(\mathrm{SO}_{4}\right)_{6} \cdot \mathrm{H}_{2} \mathrm{O}$ and $(\mathrm{Ca}, \mathrm{Na})_{2}(\mathrm{Si}, \mathrm{Al})_{5} \mathrm{O}_{10} \cdot 3 \mathrm{H}_{2} \mathrm{O}$ play a key role in fixation of alkali metal elements, and the coordination of CSH gel cementation effect and AFt filling effect has a significant impact on mechanical properties. The study provides an effective way to the utilization of red mud and desulfurization gypsum in subgrade strengthening.
\end{abstract}

\section{Introduction}

As an effective measure for soil stabilization, cementedbased stabilization has been widely used in engineering such as base material for pavement, foundation stabilization, and subgrade strengthening [1]. However, cemented soil has disadvantages in strength and durability [2] and improving the performance of cemented soil is essential for its application. In cold regions, when temperature drops below $0^{\circ} \mathrm{C}$ in winter, the pore water freezes and causes volume expansion, which seriously endangers the safety of public transport [3]. As a byproduct of industrial production, solid waste has huge reserves and improper disposal of solid waste could cause critical environmental hazards. The utilization of solid waste in composite cemented soil and other civil engineering has great potential [4-7].
As a metallic element widely existing in nature, aluminum occupies a significant position in the process of industrialization. Red mud is the byproduct of extracting alumina from bauxite ore. The production of $1 \mathrm{t}$ alumina will also produce approximately $1 \mathrm{t}$ to $1.5 \mathrm{t}$ of red mud [8]. Today, the main methods of red mud disposal are slurry disposal, dry stacking, and marine disposal [9]. Thermal power generation still occupies a considerable share in China, and desulfurization gypsum is the byproduct produced in the process of flue gas desulfurization in coal-fired power plants [10]. The utilization of solid waste can not only consume a large amount of solid waste but also reduce the environmental burden.

Over the years, many attempts have been reported to explore the utilization of red mud as building materials [11], treatment of contaminated soils [12], and raw materials for 
the extraction of the metal elements [13]. In addition, there are many reports for the application of red mud in the construction for road traffic. Alam et al. [14] used alkaliactivated ground granulated blast furnace slag (GGBS) to stabilize red mud as the geotechnical material and tested its durability in the drying-wetting cycles. The leaching toxicity tests showed that the stabilized red mud was nontoxic. Zhang et al. [15] used red mud, blast furnace slag, cement clinker, and gypsum to develop new cement-based material. Mukiza et al. [16] added red mud and fly ash to the subgrade material. The research and development of the application of desulfurization gypsum is mainly concentrated on building materials and other fields $[17,18]$.

For the red mud-cement stabilized soil, many research studies also have been reported. Mi et al. [19] studied the permeability of cemented soil mixed with red mud and pointed out that the additive of red mud greatly reduces the permeability coefficient. Tian et al. [20] investigated the effect of simulated acid rain on red mud-cement stabilized soil. Results showed that the permeability coefficient decreased with the increase of sulfuric acid concentration. Chen et al. [21] added a small amount of cement and red mud to strengthen the loess roadbed filling and analyzed the mechanical properties, dynamic properties, and microstructural properties of the stabilized soil. Salih et al [22] applied red mud, fly ash, and desulfurization gypsum to subgrade materials and studied the mechanical properties and durability to drying-wetting cycles. These provide a reference for the application of red mud in civil engineering.

Many researchers have explored the reductions of the mechanical properties of the stabilized soil after freezingthawing cycles and its mechanism. Jafari and Esna-Ashari [23] added waste tire to modified clay with lime and studied the mechanical properties of modified soil under freezingthawing cycle. Liu et al. [24] studied the dynamic properties of cement and lime modified clay soils used on high-speed railways in northern China after freezing-thawing cycle. Compared to unimproved soil, the critical dynamic stress of lime-modified soil and cement-modified soil increased by $60 \%$ and $200 \%$, respectively. Aldaood et al. [25] added gypsum to lime stabilized soil and investigated the mechanical properties and microscopic mechanism during freezing-thawing cycle. The results showed that strength decreased after 5 freezing-thawing cycles. Liu et al. [26] used red mud and coal gangue as raw materials for road base and carried out freezing-thawing cycle tests.

As an inherent characteristic of rocks and soils, resistivity can be used to characterize the variation in internal structure. Zha et al. [27] studied the resistivity characteristics of contaminated soil solidified by cement and fly ash. The results showed that unconfined compressive strength and resistivity maintain linear relationships on a semilog scale. Mosavinejad et al. [28] used different kinds of materials as electrodes and tested the resistivity of composite cemented soil. The results showed that brass was more suitable as an electrode material than pure copper and steel. Dong et al. [29-31] did a lot of research studies on the relationship between unconfined compressive strength and resistivity of cemented soil under complex environments. Under the freezing-thawing cycle condition, the internal structure of the materials changes and the resistivity also changes accordingly. Wang et al. [32] used silica fume, fly ash, groundgranulated blast furnace slag, and steel slag as additives to ordinary Portland cement and test the resistivity under freezing-thawing cycles. Fu and Wang [33] tested the resistivity of silt clay from the Qinghai-Tibet Plateau under freezing-thawing cycles and indicated that the resistivity variation corresponded to soil deformation.

In spite of the mentioned studies, there are few studies on the mechanism of interaction between $\mathrm{CSH}$ gel and $\mathrm{AFt}$ in red mud-calcium-based composite materials and fixation of alkali metal elements in red mud-based materials. Furthermore, the pressure sensitivity of stabilized soil under freezing-thawing cycles has not been investigated yet.

The objective of this study is to evaluate the feasibility of red mud and desulfurization gypsum in subgrade strengthening under freezing-thawing cycle condition and to reveal the action mechanism of $\mathrm{CSH}$ gel and AFt in RMCC from a microscopic perspective. Moreover, the mechanism of alkali metal elements fixation of RMCC is also studied. Firstly, the mechanical properties were assessed by compressive strength tests and a serious of freezing-thawing cycle tests were carried out. Thereafter, the resistivity and pressure sensitivity of RMCC was studied. Finally, the microstructural properties were revealed by X-ray diffraction (XRD) and scanning electron microscope (SEM and EDS). This paper provides a theoretical support for the utilization of red mud and desulfurization gypsum in subgrade strengthening.

\section{Materials and Methods}

2.1. Materials. The red mud was excavated from Xiaoyi, Shanxi Province in China. It belongs to the Bayer method red mud. Figure 1 shows the SEM image and XRD pattern of red mud. The magnification in Figure 1(a) is 10,000 which indicates that the particle size is small and an aggregate microstructure composed of massive fine particles can be observed. The red mud contains $\mathrm{CaCO}_{3}, \mathrm{Al}_{2} \mathrm{O}_{3}, \mathrm{Al}(\mathrm{OH})_{3}$, and Calcium Silicate Hydrate. The specific surface area of red mud is $1217 \mathrm{~m}^{2} / \mathrm{kg}$. The desulfurization gypsum (FGD) was excavated from Taiyuan Power Plant in Shanxi Province. Figure 2 shows the SEM image and XRD pattern of desulfurization gypsum. The desulfurization gypsum particles are regular in prismatic shape and the particle size is large. $\mathrm{XRD}$ analysis reveals that desulfurization gypsum is mainly composed of $\mathrm{CaSO}_{4} \cdot 2 \mathrm{H}_{2} \mathrm{O}, \quad \mathrm{CaSO}_{4} \cdot 0.5 \mathrm{H}_{2} \mathrm{O}$, and $\mathrm{CaSO}_{4} \cdot 0.62 \mathrm{H}_{2} \mathrm{O}$. The solubility of $\mathrm{CaSO}_{4} \cdot 0.5 \mathrm{H}_{2} \mathrm{O}$ and $\mathrm{CaSO}_{4} \cdot 0.62 \mathrm{H}_{2} \mathrm{O}$ is greater than that of $\mathrm{CaSO}_{4} \cdot 2 \mathrm{H}_{2} \mathrm{O}$ [34]. The specific surface area of desulfurized gypsum is $926.3 \mathrm{~m}^{2} /$ $\mathrm{kg}$. The loess was excavated from Taiyuan, Shanxi Province and the specific surface area of loess is $227.3 \mathrm{~m}^{2} / \mathrm{kg}$. The cement is ordinary Portland cement $(42.5 \mathrm{R} / \mathrm{N})$. Figure 3 shows the particle size distribution of red mud, desulfurization gypsum, and loess. Table 1 shows the basic physical properties of loess. The chemical composition of raw materials is listed in Table 2. Note that the alkali metal oxides are the source of alkalinity of red mud. 

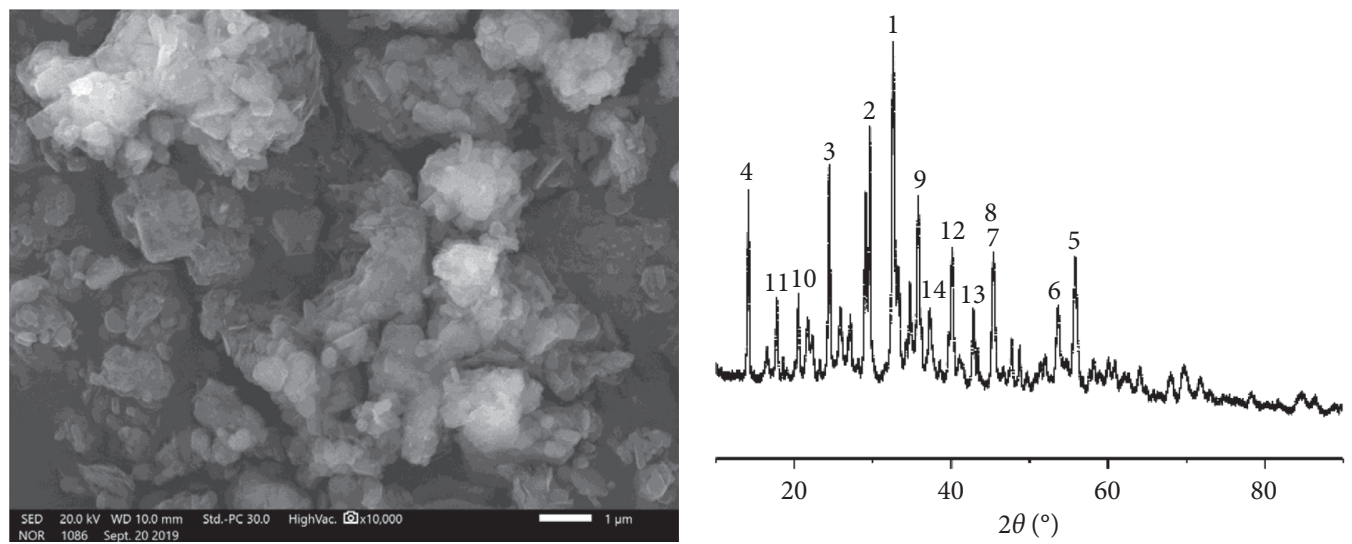

1 Vaterite- $\mathrm{CaCO}_{3}$

2 Riversideite- $\mathrm{Ca}_{5} \mathrm{Si}_{6} \mathrm{O}_{16}(\mathrm{OH})_{2}$

3 Cancrinite- $\mathrm{Na}_{6} \mathrm{Ca}_{2} \mathrm{Al}_{6} \mathrm{Si}_{6} \mathrm{O}_{24}\left(\mathrm{CO}_{3}\right)_{2} \cdot 2 \mathrm{H}_{2} \mathrm{O}$

4 Alumohydrocalcite- $\mathrm{CaAI}_{2}\left(\mathrm{CO}_{3}\right)_{2}(\mathrm{OH})_{4} \cdot 3 \mathrm{H}_{2} \mathrm{O}$

5 Calcium Iron Oxide- $\mathrm{CaFe}_{5} \mathrm{O}_{7} \mathrm{CaFe}_{5} \mathrm{O}_{7}$

6 Calcium Silicate Hydrate- $\mathrm{Ca}_{3} \mathrm{Si}_{2} \mathrm{O}_{7} \cdot 3 \mathrm{H}_{2} \mathrm{O}$

7 Calcium Silicate Hydrate-CaO-SiO- $\mathrm{H}_{2} \mathrm{O}$

8 Katoite, silicatian- $\mathrm{Ca}_{3} \mathrm{AI}_{2}\left(\mathrm{SiO}_{4}\right)(\mathrm{OH})_{8}$

9 Thaumasite $-\mathrm{Ca}_{3} \mathrm{Si}\left(\mathrm{SO}_{4}\right)_{2}(\mathrm{OH})_{6} \cdot 9 \mathrm{H}_{2} \mathrm{O}$

10 Gibbsite, syn- $\mathrm{AI}(\mathrm{OH})_{3}$

11 Kalinite- $\mathrm{KAI}\left(\mathrm{SO}_{4}\right)_{2} \cdot 11 \mathrm{H}_{2} \mathrm{O}$

12 Aluminum Oxide- $\mathrm{AI}_{2} \mathrm{O}_{3}$

13 Hibonite- $5 \mathrm{H}$, syn- $\mathrm{CaAI}_{12} \mathrm{O}_{19}$

14 Lime, syn-CaO

(a)

(b)

FIgURE 1: SEM and XRD analyses of red mud. (a) SEM image $\times 10000$. (b) XRD pattern.

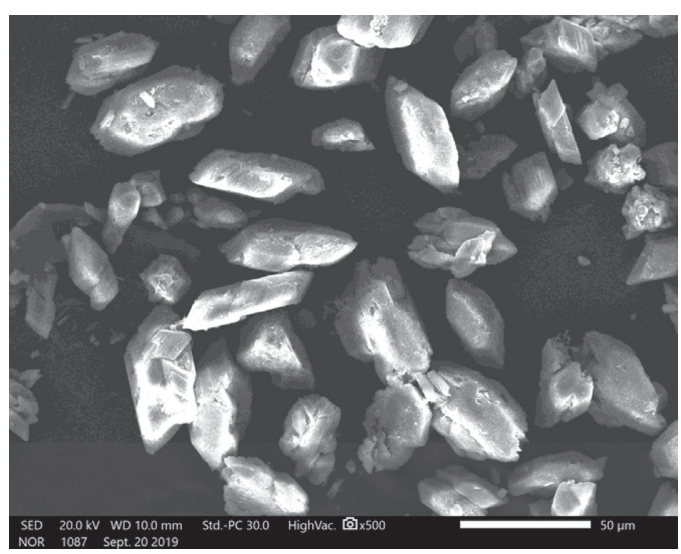

(a)

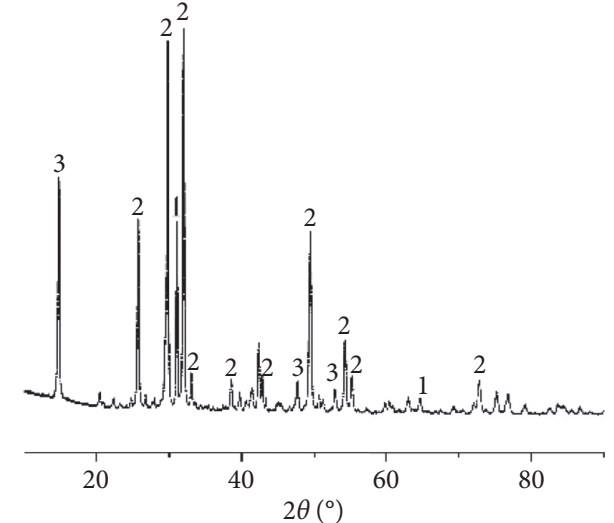

1 Gypsum, syn- $\mathrm{CaSO}_{4} \cdot 2 \mathrm{H}_{2} \mathrm{O}$

2 Bassanite, syn- $\mathrm{CaSO}_{4} \cdot 0.5 \mathrm{H}_{2} \mathrm{O}$

3 Calcium Sulfate Hydrate- $\mathrm{CaSO}_{4} \cdot 0.62 \mathrm{H}_{2} \mathrm{O}$

(b)

Figure 2: SEM and XRD analyses of desulfurization gypsum. (a) SEM image $\times 500$. (b) XRD pattern.

2.2. Sample Preparation. Firstly, the loess, red mud, and desulfurization gypsum were crushed and dried. Loess and red mud were sieved through a 0.075 mesh-sized sieve. For RMCC mixture, the cement accounted for $10 \%$ of loess dry mass and the red mud accounted for $50 \%$ of desulfurization gypsum dry mass, respectively (Table 3 ). Since the moisture content has a great influence on freezing-thawing cycle tests, the moisture content was set at $29 \%$. Secondly, according to the China standard JGJ/T70-2009 [35], the predetermined amounts of red mud, cement, desulfurization gypsum, and water were mixed to obtain a homogeneous mixture through concrete mixing device. Moreover, for cement-treated loess 


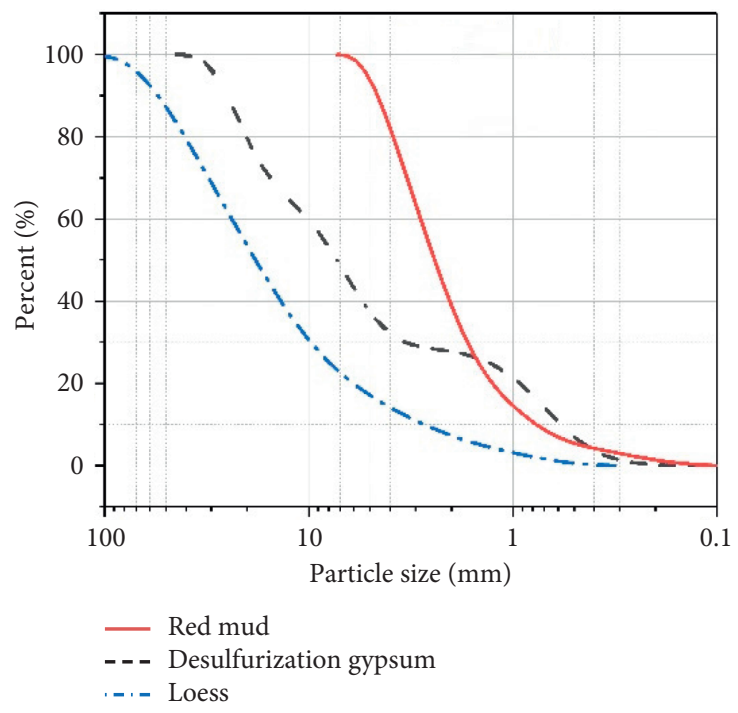

FIgURE 3: Particle size distribution of major materials.

TABLE 1: Basic physical properties of loess.

Maximum dry density $\rho_{\max }\left(\mathrm{g} \cdot \mathrm{cm}^{-3}\right)$ Optimum moisture content $\omega_{\text {opt }}(\%)$ Plastic limit $\omega_{L}(\%)$ Liquid limit $\omega_{p}(\%)$ Plasticity index $\left(I_{p}\right)$ \begin{tabular}{lllll}
\hline 1.77 & 16.7 & 25.2 & 15.3 & 9.9
\end{tabular}

TABLE 2: Chemical compositions of major materials (\%).

\begin{tabular}{lcccc}
\hline Material & Red mud (\%) & FGD (\%) & Cement (\%) & Loess (\%) \\
\hline $\mathrm{CaO}$ & 15.58 & 30.13 & 66.35 & 7.98 \\
$\mathrm{SiO}_{2}$ & 26.8 & - & 18.81 & 58.88 \\
$\mathrm{Al}_{2} \mathrm{O}_{3}$ & 24.03 & 0.05 & 5.86 & 11.75 \\
$\mathrm{Fe}_{2} \mathrm{O}_{3}$ & 6.96 & 0.03 & 3.34 & 4.54 \\
$\mathrm{MgO}$ & 1.22 & 0.17 & 1.04 & 2.05 \\
$\mathrm{Na}_{2} \mathrm{O}$ & 7.15 & - & 0.31 & 1.70 \\
$\mathrm{~K}_{2} \mathrm{O}$ & 0.76 & - & 0.41 & 2.18 \\
$\mathrm{TiO}_{2}$ & 3.42 & - & - & 0.60 \\
$\mathrm{SO}_{3}$ & - & 42.71 & 2.53 & 2.18 \\
Others & 14.08 & 26.91 & 1.35 & 8.14 \\
\hline
\end{tabular}

TABle 3: Proportion of the mixture.

\begin{tabular}{lc}
\hline Sample & Red mud:FGD: Loess \\
\hline 1 & $3: 6: 100$ \\
2 & $6: 12: 100$ \\
3 & $9: 18: 100$ \\
4 & $12: 24: 100$ \\
5 & $15: 30: 100$ \\
\hline
\end{tabular}

which will be the control group, the cement accounted for $10 \%$ and $15 \%$ of loess dry mass, respectively. Thirdly, the mixture was placed into a cube metal mold $(70.7 \mathrm{~mm}$ inside length) to obtain the RMCC samples through concrete vibrating table. Finally, the metal molds were covered with plastic film and stripped after 24 hours. The samples were maintained in a standard curing room with constant temperature and humidity for 7,14 , and 28 days, respectively. The curing temperature was $19.5-21.5^{\circ} \mathrm{C}$ and the curing humidity was $95 \%$.
Some specimens were obtained from samples after the corresponding curing period and freezing-thawing cycles for microstructure measurement. These specimens were submerged in absolute ethanol to stop the hydration process and then placed in air to dry. Some of the dried specimens were polished to the dimensions of $1 \mathrm{~cm} \times 1 \mathrm{~cm} \times 0.5 \mathrm{~cm}$ for the SEM and EDS tests, and the other dried samples were ground into a powder for the XRD tests.

\subsection{Testing Procedures}

2.3.1. Compressive Test and Resistivity Test. Compressive strength tests were conducted through a microcomputer controlled-electronic universal testing machine (WAW2000) and the samples were pressed with vertical deformation rate of $1 \mathrm{~mm} / \mathrm{min}$. Resistivity tests were conducted through LCR digital bridge (TH2828A). First step in the resistivity tests were to smooth the upper and lower surfaces of the sample. Then, graphite was applied to both sides of the sample to improve conductivity. Select a current frequency of $50 \mathrm{kHz}$ as the analysis object [30]. The data obtained by the digital bridge was the impedance $|Z|$. The resistivity is calculated according to formula

$$
\rho=\frac{|Z| S}{L}
$$

where $\rho$ is the resistivity $(\Omega \cdot \mathrm{m})$; $|Z|$ is the impedance $(\Omega)$; $S$ is the cross-sectional area of the simple $\left(\mathrm{m}^{2}\right)$; and $L$ is the distance between the electrodes $(\mathrm{m})$.

For the samples that have completed the freezingthawing cycle tests, before the resistivity tests, the surface of the samples should be dry. For the stress-strain-resistivity 
tests, copper foils were placed on the upper and lower surfaces of the samples as electrodes in the process of compressive strength test. During the loading process, load value, position value, and impedance were recorded simultaneously. Then, the corresponding data was calculated to obtain the stress-strain-resistivity data.

2.3.2. Freezing-Thawing Cycle Test. In this paper, the freezing-thawing cycle tests were conducted by SRTDR16 rapid concrete freezing-thawing testing machine. The lowest temperature was set at $-15^{\circ} \mathrm{C}$ and the highest temperature was set at $5^{\circ} \mathrm{C}$. The freezing-thawing cycle tests are following the China national standard GBT50082-200 [36]. In the first step, 3 samples were placed in a rubber cylinder. A total of 12 samples were tested for one freezing-thawing cycle. In the second step, the rubber cylinders were placed in the test equipment. The third step was to add water in the rubber cylinder and inserted the temperature sensor. After the equipment was started, the temperature was reduced to $-15^{\circ} \mathrm{C}$, and then the equipment began to heat up. When the temperature reaches $5^{\circ} \mathrm{C}$, the test was finished for one freezing-thawing cycle. Then, the samples were removed from the rubber cylinder and left at room temperature. After the corresponding freezing-thawing tests, the samples were placed for approximately $7-8$ hours in room temperature before the compressive strength test. When freezing-thawing cycle reached 7 times, the tests finished $[25,26]$.

2.3.3. Microscopic Test. To further explore the micromechanism of RMCC, a series of microscopic test was performed. The XRD analysis was conducted by Ultima IV $\mathrm{X}$-ray diffractometer. The powdery specimens were scanned ranging from $10^{\circ}$ to $90^{\circ}$ with a speed of $20^{\circ} / \mathrm{min}$. The SEM and EDS analysis were conducted by using a JSM-IT200 scanning electron microscope.

\section{Results and Discussion}

\subsection{Mechanical Properties of RMCC under Standard Curing}

3.1.1. Strength Performance under Standard Curing. Figure 4 depicts the relationship between the compressive strength $q_{u}$ value and the curing time of RMCC. It exhibits a similar trend of $q_{u}$ with the different red mud contents $\left(C_{R}\right)$. When a curing period is 14 days, the $q_{u}$, respectively, reaches $2.32,2.27,2.64,2.72$, and $2.74 \mathrm{MPa}$ with a red mud content of $3 \%, 6 \%, 9 \%, 12 \%$, and $15 \%$, respectively. It accounts for $81 \%, 74 \%, 82 \%, 83 \%$, and $89 \%$ of $q_{u}$ after 28 days-curing. From the perspective of strength, in stage one, the first 14 days, the strength of RMCC has a faster growth rate; in stage two, from day 14 to day 28 of the curing period, the strength of RMCC has a slow growth rate. This result may be attributed to that the hydration reaction rate is relatively faster in the first stage of the curing period. Moreover, the gelling hydrates such as $\mathrm{CSH}$ gel generated from hydration reaction can bond red mud particles, desulfurization gypsum

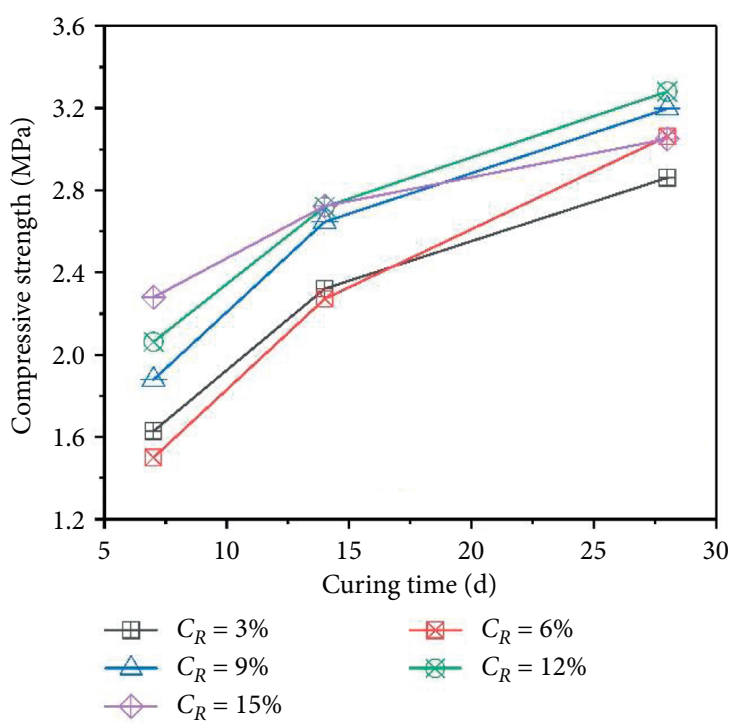

Figure 4: The relationship between compressive strength and curing time.

particles, and loess particles to form a stable and compact soil structure in the first stage [21]. However, the rate of hydration reaction in the second curing period is slowing down and leading to a slower growth in compressive strength.

Figure 5 shows the effect of red mud content on the compressive strength $q_{u}$ value under different curing time periods. With the increase of the red mud content, the $q_{u}$ of RMCC shows an increasing trend. When the red mud content exceeds $12 \%$, the $q_{u}$ shows a decreasing trend. The optimum red mud content of RMCC is $12 \%$. When the red mud content increases from 3\% to $6 \%$ after 7 -day-curing and 14-day-curing, the $q_{u}$ shows a slight decreasing trend. This result may attribute to that when the red mud content is $6 \%$, the content of desulfurized gypsum is relatively low and the AFt generated from pozzolanic reaction has a lower capacity to fill the pores so that there are more pores interior. However, when the curing time is 28 days, the hydration process is almost complete, and the structure is stable.

\subsubsection{Resistivity Performance under Standard Curing.} Figure 6 shows the relationship between resistivity and red mud content under different curing time periods. With the increase of red mud content, resistivity first increases and then decreases. When the red mud content is $12 \%$, the resistivity reaches its maximum value. The alkalinity of the RMCC system is low with the low red mud content, resulting in the loss formation of $\mathrm{CSH}$ gel and AFt. Therefore, there are more pores in the interior which result in low resistivity. With an increase of the red mud content, the hydration reaction and pozzolanic reaction are facilitated, the internal structure tends to be stable, resulting in the reduction of pores and increasing of compressive strength and resistivity [29, 37]. When the red mud content is $12 \%$, the compressive strength and resistivity 


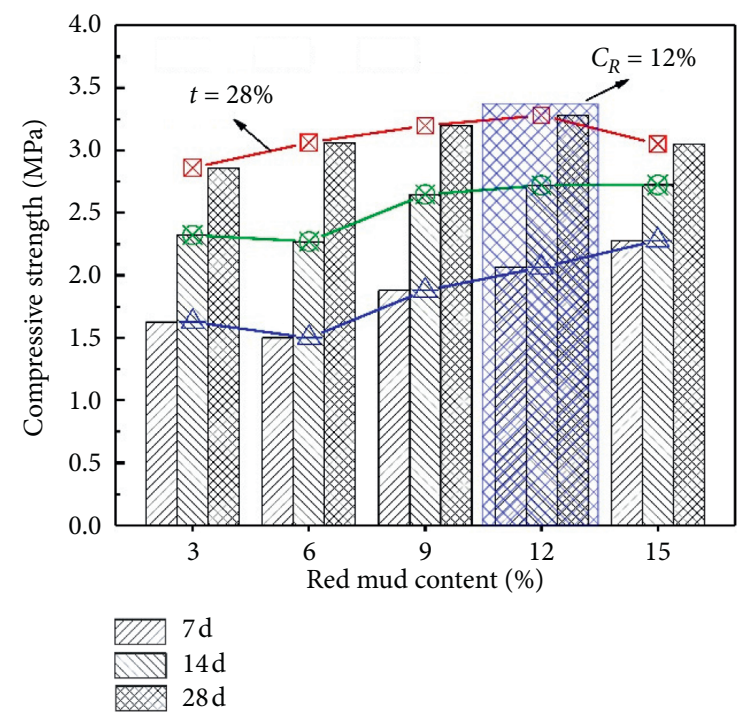

Figure 5: The relationship between compressive strength and red mud content.

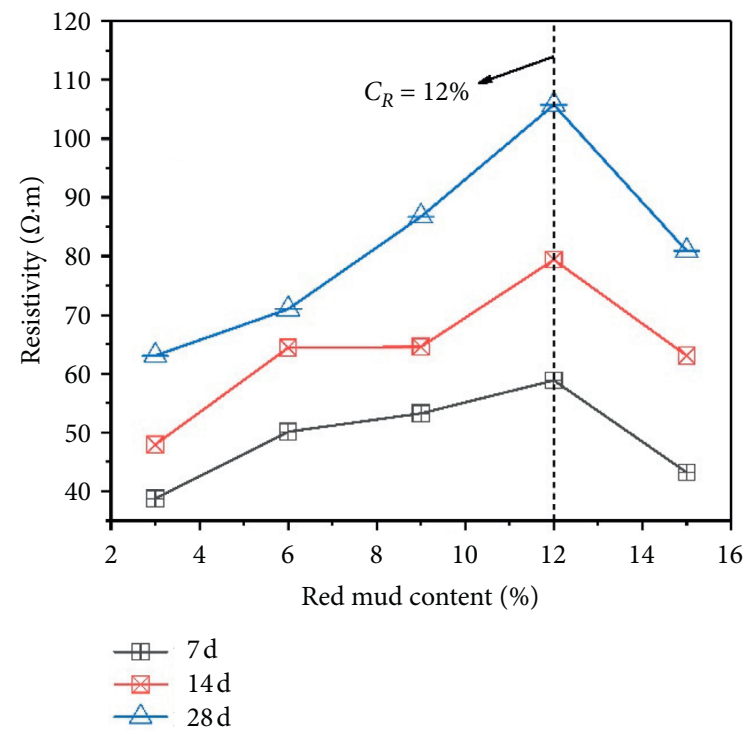

FIGURE 6: The relationship between resistivity and red mud content under different curing time periods.

reaches its maximum value, indicating stable and dense structure forms. Resistivity can be used to characterize the process of the reaction and the quantity of pores inside the samples.

\subsection{Mechanical Properties of RMCC under Freezing-Thawing Cycle}

3.2.1. Strength Performance under Freezing-Thawing Cycle. The climate variables have a huge impact on the mechanical properties of materials, so it is necessary to explore the durability RMCC to freezing-thawing cycle. For the durability index of semirigid materials under freezing-thawing cycle condition [26], it is calculated according to the following formula:

$$
\mathrm{BDR}=\left(1-\frac{f_{F T}}{f_{u}}\right) \times 100 \%,
$$

where BDR is the loss rate of compressive strength after the freezing-thawing cycle, $f_{\mathrm{FT}}$ is the residual compressive strength after the freezing-thawing cycle, and $f_{\mathrm{u}}$ is the initial compressive strength without the freezing-thawing cycle.

Figure 7 shows the relationship between the loss rate of compressive strength (BDR) and red mud content under different freezing-thawing cycles (FTC). With the increase of the red mud content, the BDR is minimum when the red mud content is $12 \%$. After 5 th and 7 th freezing-thawing cycles, the compressive strength suffered a large reduction and the two curves are relatively close to each other. It means that the sample has been severely damaged and the reduction of compressive strength value between 5 th and 7 th freezing-thawing cycle is low. As the control group, the samples of cement-treated loess are destroyed after 3 freezing-thawing cycles.

During the freezing-thawing cycles, the pore water freezes and expands $9 \%$ of its volume [38], damaging the structure of the specimen, and the peeling phenomenon will gradually become serious. Define the rate of mass loss to the following formula:

$$
\Delta_{n}=\frac{m-m_{n}}{m} \times 100 \%
$$

where $\Delta_{n}$ is the rate of mass loss after $n$ freezing-thawing cycles. $m_{n}$ is the mass of the sample after $n$ freezing-thawing cycles and $m$ is the mass of the initial sample without the freezing-thawing cycle.

Figure 8 shows the relationship between the mass loss rate and red mud content under different freezingthawing cycles. After 1 or 2 freezing-thawing cycles, the rate of mass loss of all specimens fluctuates around $1 \%$. After 3 freezing-thawing cycles, the mass loss rate increases faster as red mud content is 3\%. After 4-6 freezing-thawing cycles and if the red mud content is 3\% and $15 \%$, the mass loss rate is relatively large. At the same time, with the red mud content of $6 \%, 9 \%$, and $12 \%$, the value of mass loss shows a tendency to gradually increase, but the range of variation is within $1 \%$. After 7 freezingthawing cycles, the mass loss rate shows a large difference. This result may attribute to the exfoliation on surface of the samples, which means that the hydration products cannot cement the raw material particles, resulting in a large increase of the mass loss rate. Combined with the analysis of compressive strength, the largest reduction of mechanical properties indicates that the RMCC is losing the durability to freezing-thawing cycles.

The variations at the rate of mass loss can characterize the durability of RMCC under freezing-thawing cycle condition [39]. By analyzing the effect of different freezingthawing cycles on the rate of mass loss, the 3rd freezingthawing cycle is an inflection point, and the 6th freezingthawing cycle is another inflection point. With the 


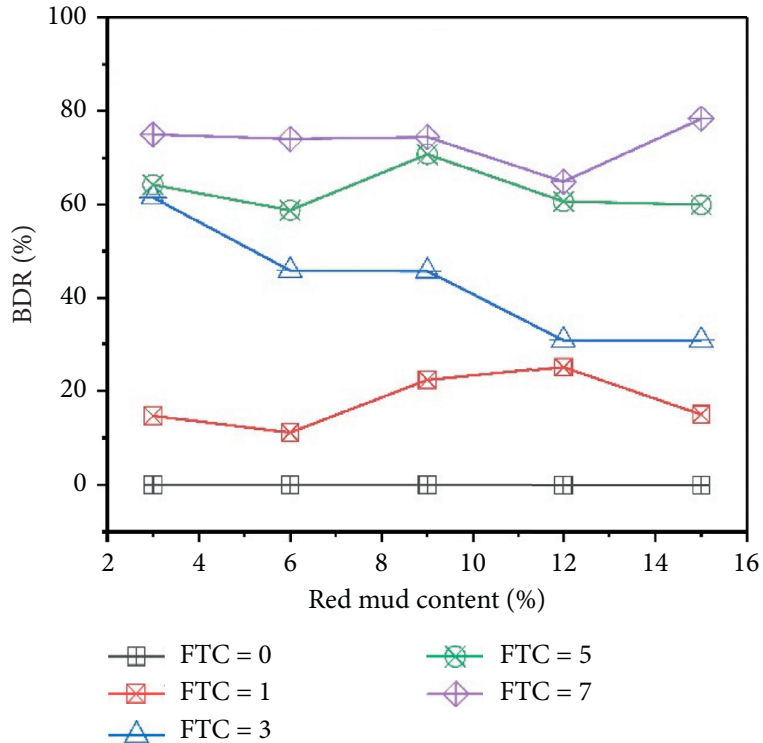

Figure 7: The relationship between BDR and red mud content.

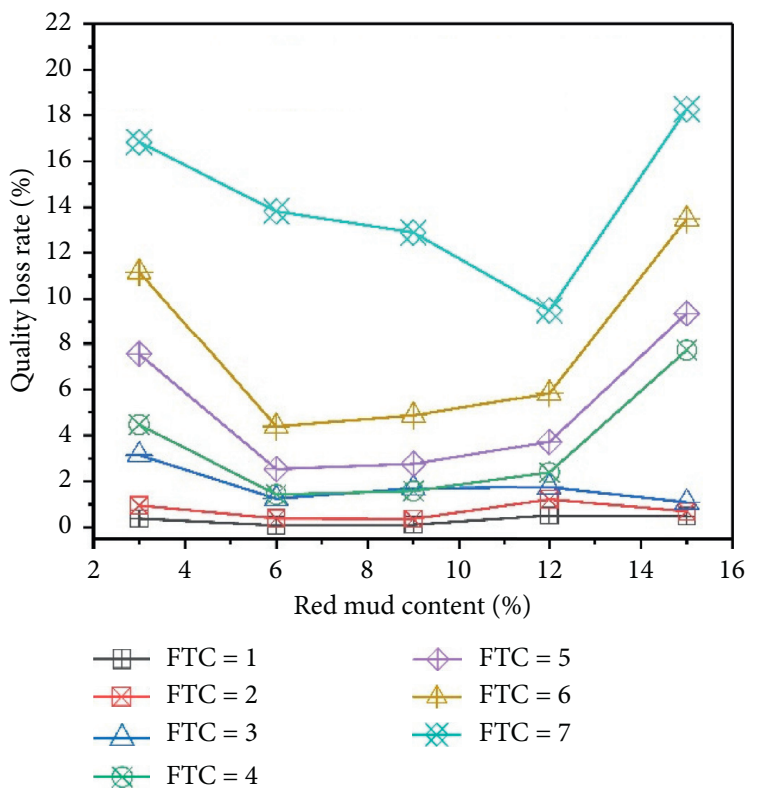

Figure 8: The relationship between the mass loss rate and red mud content.

progression of the freezing-thawing cycles, the mass loss rate is lowest when the red mud content is $12 \%$, indicating that the RMCC has the best durability to the freezing-thawing cycle at this content.

3.2.2. Resistivity Performance under Freezing-Thawing Cycle. Figure 9 shows the relationship between the resistivity and red mud content under freezing-thawing cycle condition. The curve of resistivity exists a remarkable peak value without the freezing-thawing cycle. After 1st or 3rd freezingthawing cycles, the peak value of resistivity weakens at the

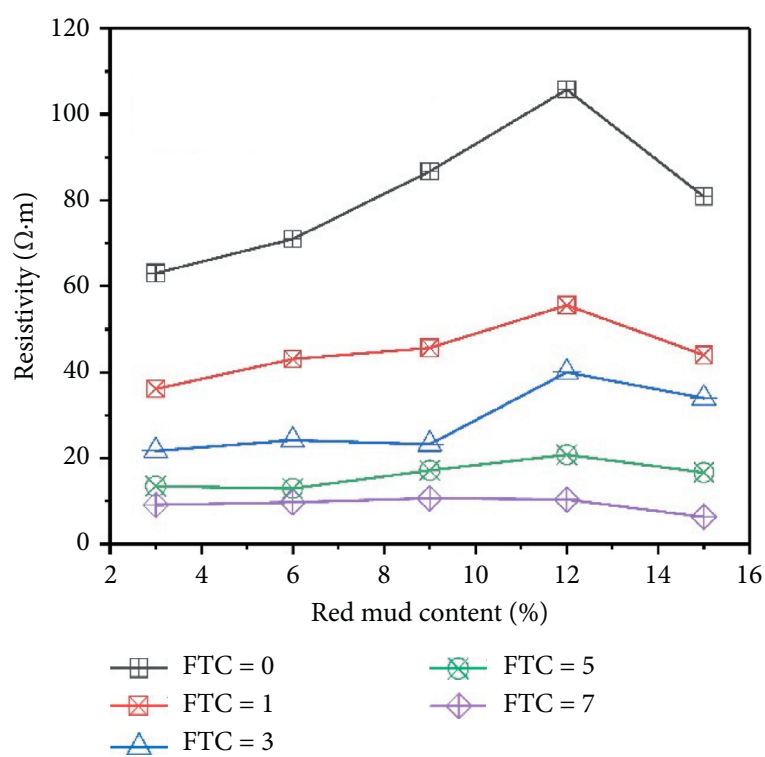

FIgURE 9: The relationship between resistivity and red mud content under the freezing-thawing cycle.

red mud content of $12 \%$, but there still exists a peak value. After 5th or 7 th freezing-thawing cycles, the peak value disappeared, and the variation of resistivity curves is similar to a straight line.

Figure 10 shows the resistivity-strain 3D Ribbons with a red mud content of $12 \%$ under different freezingthawing cycles. It can be observed that the freezingthawing cycle has a large effect on 3D Ribbons and different Ribbons show large differences. After the 1st freezing-thawing cycle, the resistivity shows a rapidly decreasing trend with increasing of strain. After the $3 \mathrm{rd}$ and 5 th freezing-thawing cycles, the resistivity decreases as the strain decreases, but the rate of decrease slows down. However, after the 7 th freezing-thawing cycle, the resistivity-strain 3D Ribbon is close to flat, and the resistivity changes little with increasing strain, which shows that with the progression of freezing-thawing cycles, the pressure sensitivity of RMCC is gradually reducing.

Combined with the analysis of compressive strength, mass loss rate, and resistivity of specimens, RMCC has the lowest strength and the largest mass loss and very little variation in resistivity after 7 freezing-thawing cycles, indicating that the internal structure has been severely damaged. At this point, the ability of hydration products such as CSH gel cement the raw material particles is lost. The above analysis shows that, after 7 freezing-thawing cycles, the formation factor of the RMCC has little effect. At the same time, among the factors influencing pressure sensitivity characteristic of samples, the change in resistivity caused by pore water dominates, and the stress-strain variations cannot have a major effect on the resistivity. The variation in pressure sensitivity effectively reflects the damage in internal structure of RMCC under freezingthawing cycle condition [40]. 


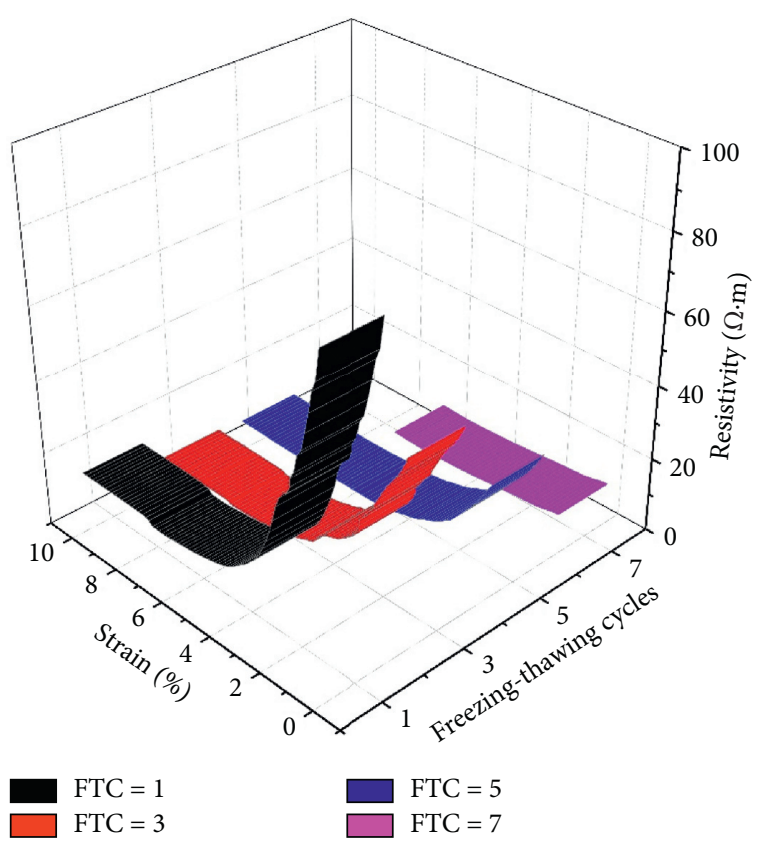

FIGURE 10: Resistivity-strain 3D ribbons of RMCC.

\subsection{Microstructure Analysis of RMCC}

3.3.1. X-Ray Diffraction Analysis. The XRD analysis was conducted to explore the formation of compounds for RMCC. Figure 11 presents the XRD pattern of specimens with 7-day-curing time and 28-day-curing time. Moreover, a sample after a 56-day-curing was also tested in order to make the analysis more complete. By comparing the XRD patterns, the compounds are basically similar in the mineralogical level, but some peaks appear or disappear within a certain range of degrees. The XRD patterns of 7-day-sample and 28-day-sample show similarities, while the XRD pattern of 56-day-sample shows more significant differences. The comparison shows that the specimen of 56-day-sample has a disappearance peak near $10^{\circ}$. This peak represents $\mathrm{CaSO}_{4} \cdot 2 \mathrm{H}_{2} \mathrm{O}$, and the peaks which also represent $\mathrm{CaSO}_{4} \cdot 2 \mathrm{H}_{2} \mathrm{O}$ disappear in the range between $31.43^{\circ}$ and $33.34^{\circ}$, indicating that $\mathrm{CaSO}_{4} \cdot 2 \mathrm{H}_{2} \mathrm{O}$ was consumed in pozzolanic reaction. The peak of Yugawaalite- $\mathrm{Ca}\left(\mathrm{Si}_{6} \mathrm{Al}_{2}\right)$ $\mathrm{O}_{16} \cdot 4 \mathrm{H}_{2} \mathrm{O}$ can be observed at $18.86^{\circ}$ in the pattern of 7-daysample, but the same peak cannot be observed in the pattern of 56-day-sample. The peak which represents $\mathrm{CaSO}_{4}$ or Epistilbite- $\mathrm{Ca}_{2}\left(\mathrm{Si}_{9} \mathrm{Al}_{3}\right) \mathrm{O}_{24} \cdot 8 \mathrm{H}_{2} \mathrm{O}$ can be observed at $23.02^{\circ}$, but cannot be observed in pattern of 56-day-sample. Three types of minerals can be observed in the pattern of 7-daysample in the range between $27^{\circ}$ and $28^{\circ}$. However, only one mineral can be observed in 56-day-sample in the same range, the peaks which represent Akdalaite- $\left(\mathrm{Al}_{2} \mathrm{O}_{3}\right)_{4} \cdot \mathrm{H}_{2} \mathrm{O}$ and Epistilbite- $\mathrm{Ca}_{2}\left(\mathrm{Si}_{9} \mathrm{Al}_{3}\right) \mathrm{O}_{24} \cdot 8 \mathrm{H}_{2} \mathrm{O}$ disappear. In the range between $34^{\circ}$ and $38^{\circ}$, two peaks disappear in patterns of 28 day-sample and 56-day-sample, which represent Prehnite$\mathrm{Ca}_{4} \mathrm{Al}_{2} \mathrm{O}_{7} \cdot 19 \mathrm{H}_{2} \mathrm{O}$ and Calcium Aluminum Oxide Hydrate$\mathrm{Ca}_{4} \mathrm{Al}_{2} \mathrm{O}_{7} \cdot 19 \mathrm{H}_{2} \mathrm{O}$. The analysis of XRD reveals that, with increasing curing period, the types of reaction products in RMCC gradually decrease, and the components tend to be stable and $\mathrm{CSH}$ gel, Aft, and $\mathrm{CaCO}_{3}$ can be observed in specimens of three different curing periods [15]. The formation of $\mathrm{CaCO}_{3}$ is attributed to carbonation reaction [41]. The products of pozzolanic reaction, carbonation reaction, ion exchange reaction, and hydration reaction play a key role in the strength of RMCC.

Compared to the pattern of 7-day-sample, two minerals with different elemental compositions can be found in the pattern of 56-day-sample: Gorgeyite- $\mathrm{K}_{2} \mathrm{Ca}_{5}\left(\mathrm{SO}_{4}\right)_{6} \cdot \mathrm{H}_{2} \mathrm{O}$ and Rustumite- $\mathrm{Ca}_{10}\left(\mathrm{Si}_{2} \mathrm{O}_{7}\right)_{2} \mathrm{SiO}_{4} \mathrm{C}_{12}(\mathrm{OH})_{2}$. The formation of two minerals can be explained by the differences between desulfurized gypsum and other gypsum such as analytical pure gypsum and construction gypsum, which is that desulfurization gypsum contains a small amount of ions such as $\mathrm{Cl}^{-}, \mathrm{Mg}^{2+}, \mathrm{Na}^{+}$, and $\mathrm{K}^{+}[41,42]$. In the hydration reaction, $\mathrm{Ca}^{2+}$ reacts with $\mathrm{Cl}^{-}$and other anions, $\mathrm{SO}_{4}^{2-}$ reacts with $\mathrm{K}^{+}$ ions, and other cations, thus forming minerals such as Gorgeyite and Rustumite. This indicates that the addition of desulfurized gypsum can facilitate the formation of hydration products. Moreover, it can be observed that there are two peaks of minerals containing sodium and potassium elements in XRD patterns: Gorgeyite- $\mathrm{K}_{2} \mathrm{Ca}_{5}\left(\mathrm{SO}_{4}\right)_{6} \cdot \mathrm{H}_{2} \mathrm{O}$ and Gonnardit- $(\mathrm{Ca}, \mathrm{Na})_{2}(\mathrm{Si}, \mathrm{Al})_{5} \mathrm{O}_{10} \cdot 3 \mathrm{H}_{2} \mathrm{O}$. The silicate hydrate formed by the hydration process in RMCC contains active $\mathrm{Ca}^{2+}$, which occurs as a replacement reaction with alkali metal elements in red mud to achieve the fixation of alkali metal elements, indicating that RMCC has alkaline binding capacity.

3.3.2. Microstructure Analysis. Figure 12 shows the SEM images and corresponding EDS analysis of RMCC after 28day curing time with a red mud content of $12 \%$. Figure 12 (a) is the partial enlarged view of desulfurization gypsum particle; Figures 12(b), 12(c), 12(e), and 12(g) are SEM images under different magnification. Figures $12(\mathrm{f})$ and 12(h) are EDS analysis corresponding to the area of Figures 12(e) and 12(g).

Compared with the edges and corners in Figures 12(a) and 12(b), it can be confirmed that Figure 12(b) shows the desulfurization gypsum particle. This indicates that the pores between desulfurization gypsum particles which have larger particle size are filled with fine particles, and all the raw material particles are cemented by the gelling products to form a stable and dense structure. In Figure 12(c), the microstructure is dense, and a large amount of gel hydrate can be observed. Figure 12 (d) is the 20,000 magnified image of the circled area in Figure 12(c). In Figure 12(d), obvious plaque-shaped substances can be observed. Combined with the related research [43], it can be recognized as $\mathrm{Ca}(\mathrm{OH})_{2}$. At the same time, a regular hexagonal flake-shaped substance can be observed in the square area of Figure 12(d). Combined with the SEM analysis of the red mud material, it can be considered as unreacted red mud particles. The filling effect of fine red mud particles can enhance the mechanical properties of RMCC.

Referring to the EDS analysis results (see Figures 12(f) and $12(\mathrm{~h})$ ), it is evident that a large amount of hydration products can be observed such as CSH gel and AFt [44, 45]. 


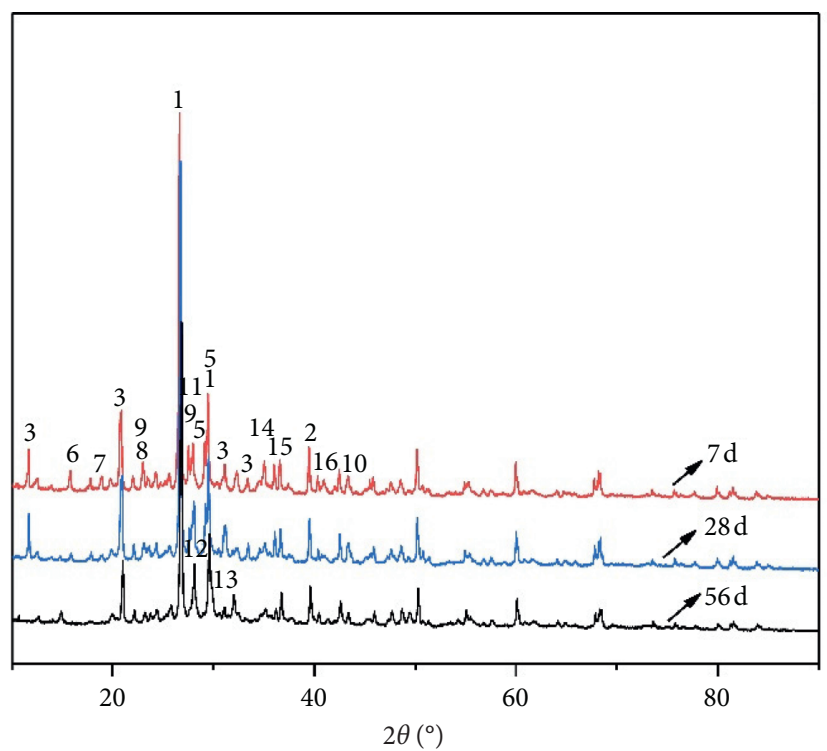

1-Quartz- $\mathrm{SiO}_{2}$

2-Calcium Oxide - $\mathrm{CaO}$

3-Gypsum- $\mathrm{CaSO}_{4} \cdot 2 \mathrm{H}_{2} \mathrm{O}$

4-Calcite- $\mathrm{CaCO}_{3}$

5-Calcium Silicate Hydrate- $\mathrm{Ca}_{6} \mathrm{Si}_{3} \mathrm{O}_{12} \cdot \mathrm{H}_{2} \mathrm{O}$

6-Ettringite- $\mathrm{Ca}_{6} \mathrm{Al}_{2}\left(\mathrm{SO}_{4}\right)_{3}(\mathrm{OH})_{12} \cdot 26 \mathrm{H}_{2} \mathrm{O}$

7-Yugawaralite- $\mathrm{Ca}\left(\mathrm{Si}_{6} \mathrm{Al}_{2}\right) \mathrm{O}_{16} \cdot 4 \mathrm{H}_{2} \mathrm{O}$

8-Calcium Sulfate- $\mathrm{CaSO}_{4}$

9-Epistilbite- $\mathrm{Ca}_{2}\left(\mathrm{Si}_{9} \mathrm{Al}_{3}\right) \mathrm{O}_{24} \cdot 8 \mathrm{H}_{2} \mathrm{O}$

10-Corundum, syn $-\mathrm{Al}_{2} \mathrm{O}_{3}$

11-Akdalaite- $\left(\mathrm{Al}_{2} \mathrm{O}_{3}\right)_{4} \cdot \mathrm{H}_{2} \mathrm{O}$

12-Gorgeyite- $\mathrm{K}_{2} \mathrm{Ca}_{5}\left(\mathrm{SO}_{4}\right)_{6} \cdot \mathrm{H}_{2} \mathrm{O}$

13-Rustumite $\mathrm{Ca}_{10}\left(\mathrm{Si}_{2} \mathrm{O}_{7}\right)_{2} \mathrm{SiO}_{4} \mathrm{C}_{12}(\mathrm{OH})_{2}$

14-Prehnite- $\mathrm{Ca}_{2} \mathrm{Al}_{2} \mathrm{Si}_{3} \mathrm{O}_{10}(\mathrm{OH})_{2}$

15-Calcium Aluminum Oxide Hydrate- $\mathrm{Ca}_{4} \mathrm{Al}_{2} \mathrm{O}_{7} \cdot 19 \mathrm{H}_{2} \mathrm{O}$

16-Gonnardite- $(\mathrm{Ca}, \mathrm{Na})_{2}(\mathrm{Si}, \mathrm{Al})_{5} \mathrm{O}_{10} \cdot 3 \mathrm{H}_{2} \mathrm{O}$

Figure 11: XRD pattern of samples at different curing time periods $\left(C_{R}=12 \%\right)$.

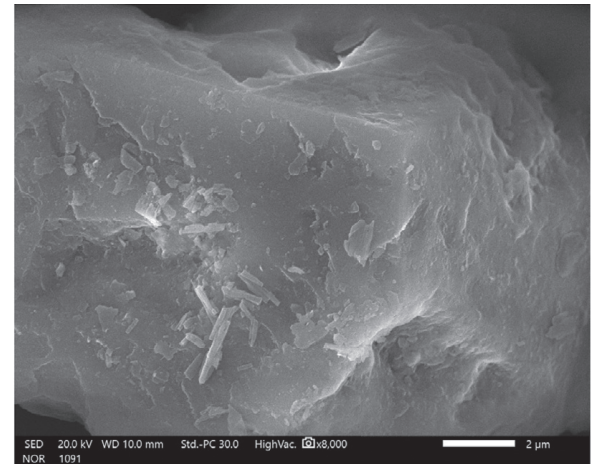

(a)

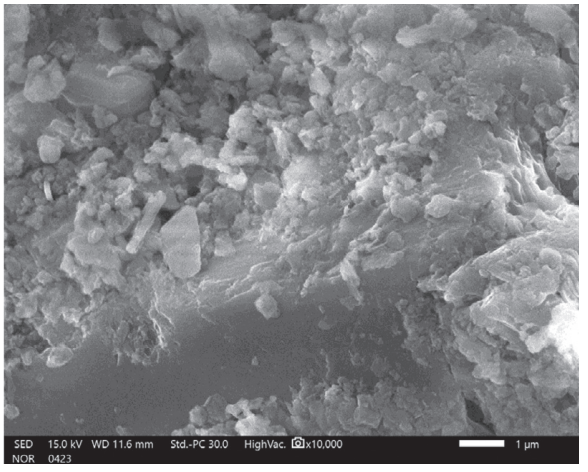

(b)

Figure 12: Continued. 


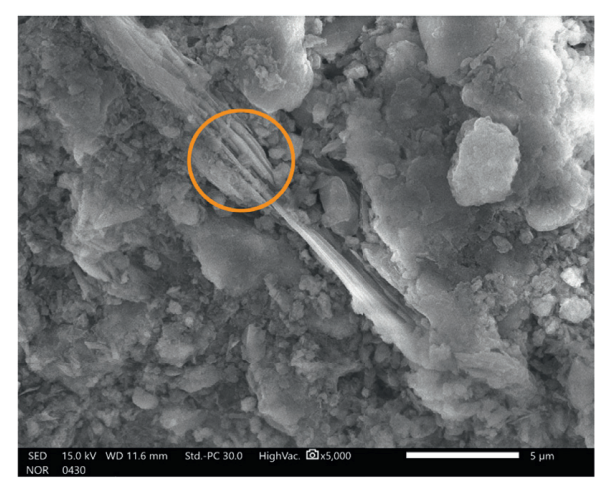

(c)

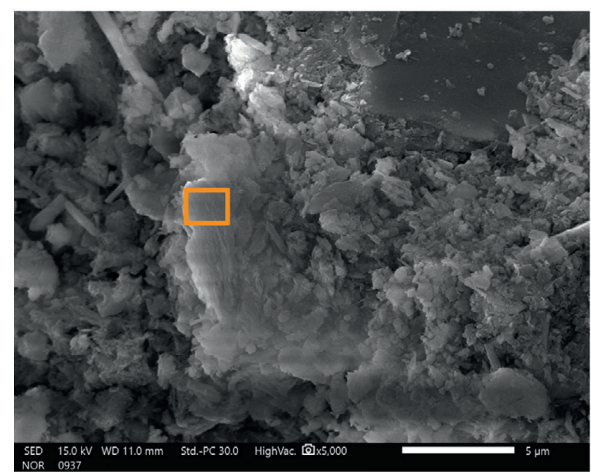

(e)

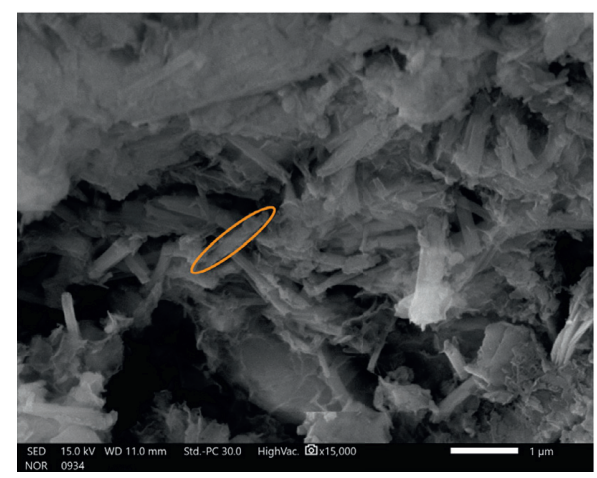

(g)

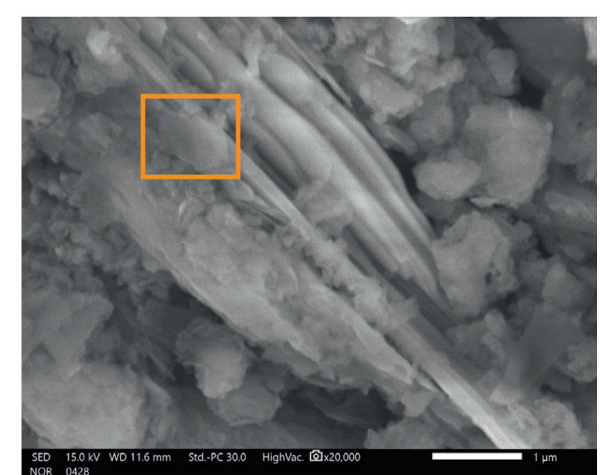

(d)

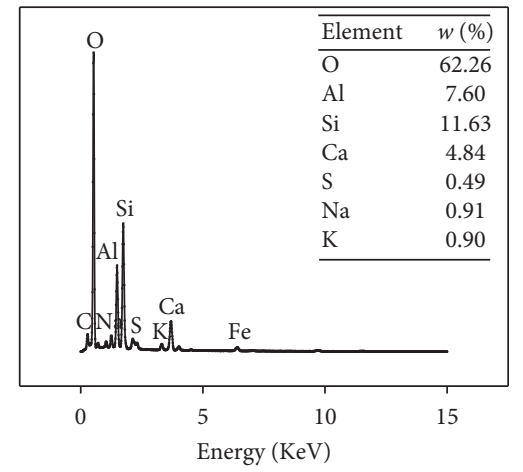

(f)

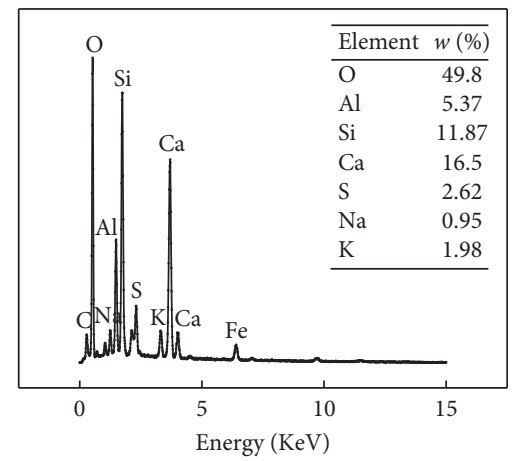

(h)

Figure 12: SEM and EDS analysis of RMCC $\left(C_{R}=12 \%\right)$. (a) $\times 8000,(\mathrm{~b}) \times 10000,(\mathrm{c}) \times 5000,(\mathrm{~d}) \times 20000,(\mathrm{e}) \times 5000$, and $(\mathrm{g}) \times 15000$.

Moreover, the alkali metal element such as $\mathrm{Na}$ and $\mathrm{K}$ can be found in the analysis of elemental composition. Combined with the presence of Gorgeyite- $\mathrm{K}_{2} \mathrm{Ca}_{5}\left(\mathrm{SO}_{4}\right)_{6} \cdot \mathrm{H}_{2} \mathrm{O}$ and Gonnardit- $(\mathrm{Ca}, \mathrm{Na})_{2}(\mathrm{Si}, \mathrm{Al})_{5} \mathrm{O}_{10} \cdot 3 \mathrm{H}_{2} \mathrm{O}$ in XRD pattern, this is the further evidence that RMCC has ability of fixation to alkali metal elements.

For the RMCC in freezing-thawing cycles with a red mud content of $12 \%$, a series of images was captured by SEM with the magnification of 1000 because, under this magnification, the damage caused by the freeing-thawing cycles to the microstructure can be clearly and intuitively observed.

In Figures 13(a) and 13(c), it can be observed that there is a small amount of crack on the surface and the shape does not change. In Figure 13(b), there are less hydration products and more micropores compared with Figure 12(c), but the microstructure still maintains continuity after 1 freezing-thawing cycle. By comparing Figures 13(b) and 13(d), it can be seen that the microstructure became broken, and larger granular substances can be observed after 3 freezing-thawing cycles. Microstructure changed from relatively flat to uneven, but no obvious microcracks were observed in Figure 13(d). From a microscopic perspective, the soil microstructure still maintains relative continuity which results no significant detriment on the surface. However, the micropores has a greater impact on mechanical properties, so when the shape remains unchanged and mass loss is small, the compressive strength suffered a significant reduction.

Comparing Figure 13(c) with 13(e), the surface was severely damaged after 5 freezing-thawing cycles, and 


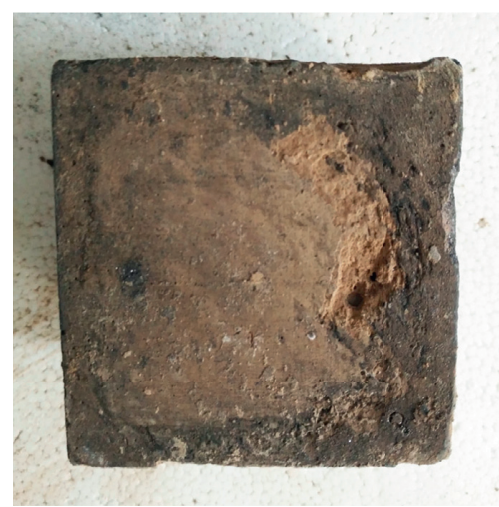

(a)

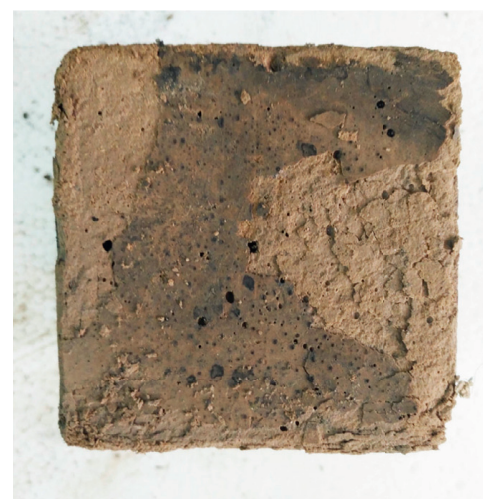

(c)

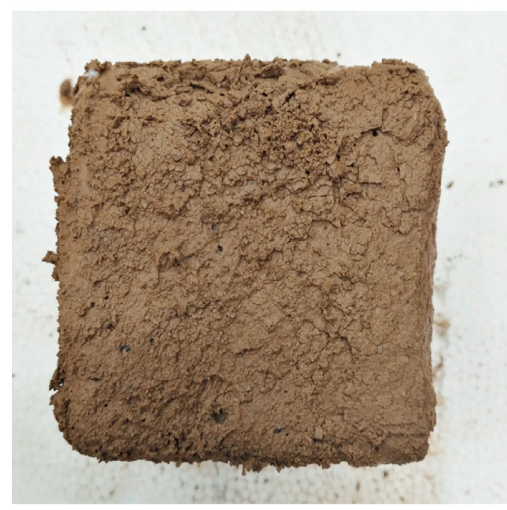

(e)

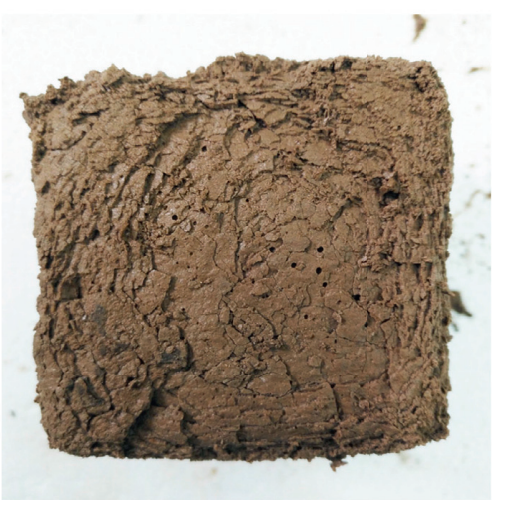

(g)

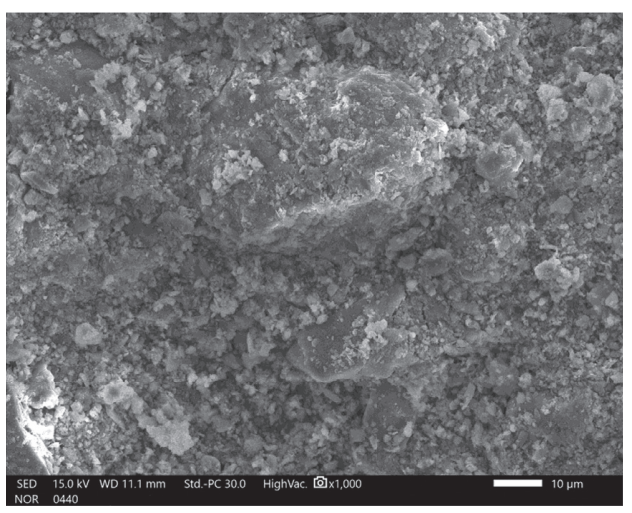

(b)

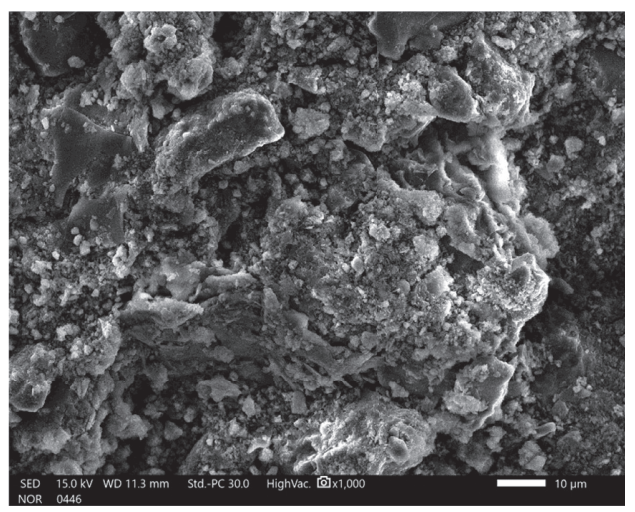

(d)

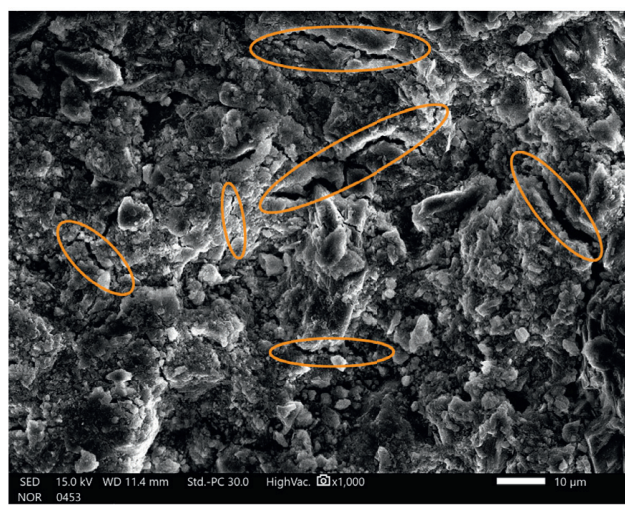

(f)

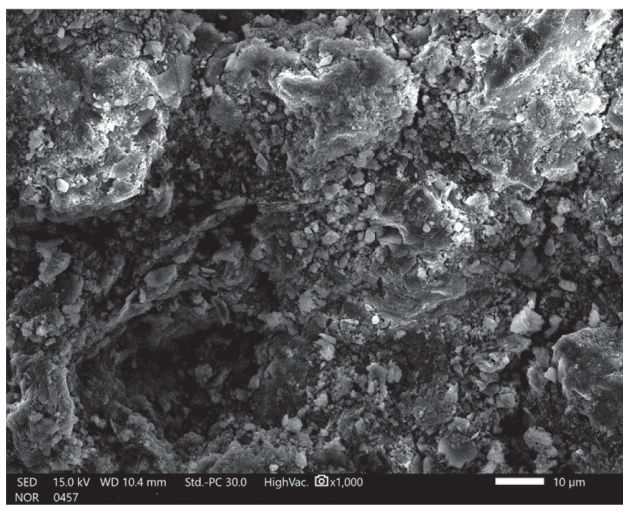

(h)

FIGURE 13: SEM images and corresponding photographs of RMCC under different freezing-thawing cycles $\left(C_{R}=12 \%\right)$. $(\mathrm{a}) \mathrm{FTC}=1,(\mathrm{c})$ $\mathrm{FTC}=3$, (e) FTC= 5, and (g) FTC=7. The magnification of (b), (d), (f), and (h) is 1000 . 
obvious crack propagation can be observed. In Figure 13(f), the microcracks shown in the elliptical frame cannot be observed in Figure 13(d). This indicates that the freezingthawing cycles result in higher degree of damage to microstructure. In Figure 13(g), the shape of sample changed after 7 freezing-thawing cycles showing the maximum damage caused by freeze-thaw cycles in macroscale. In Figure 13(h), a larger hole can be observed in the lower left corner. Compared with Figure 13(f), the destruction of microstructure changed from microcracks into the larger hole means that cementation property between raw material particles was destroyed [25]. From a macroscopic perspective, the speed of mass loss increased significantly, and the mechanical properties suffered a significant reduction.

In summary, with the progression of the freezingthawing cycles, the damage caused by the freezing process to the microstructure gradually became serious. The increase in porosity and microcracks leads to a sharp increase in damage caused by the expansion of ice lenses. After 5 freezing-thawing cycles, the RMCC do not be completely destroyed. However, most cement-treated soil in this paper was destroyed after 3 freezing-thawing cycles. Therefore, RMCC exhibits better durability against freezing-thawing cycles.

3.4. Discussion on the Mechanism. In RMCC system, the hydrolysis of loess and red mud provides active ions. At the same time, the hydrolysis of red mud improves the alkalinity of the reaction system, and the hydrolysis of desulfurized gypsum provides enough $\mathrm{Ca}^{2+}$. Under the combined action of these three phenomena, the hydration process is facilitated $[21,37]$. The nucleation of $\mathrm{Ca}^{2+}$ forms aggregates on the surface of raw material particles. These aggregates are cemented by gelling products such as CSH gel and increase the interparticle interaction. Aggregates, fine particles, and hydration products attached to the surface of desulfurized gypsum particles reduce the dissolution of $\mathrm{CaSO}_{4} \cdot 2 \mathrm{H}_{2} \mathrm{O}$ and improve water stability of RMCC $[46,47]$. The CSH gel generated by hydration reaction has a cementation effect, while the AFt generated by pozzolanic reaction has a filling effect. Therefore, when red mud content is low, the corresponding desulfurization gypsum content is also low, and the filling effect of AFt is not significant, resulting in a large quantity of micropores, low compressive strength, and poor durability against freezing-thawing cycles. When the red mud content is excessive, on the one hand, high alkalinity of the reaction system retards the hydration process. On the other hand, due to the large specific surface area of red mud [48], more gelling hydrates will be consumed in order to cement red mud particles. At the same time, high desulfurization gypsum content causes excessive AFt generated, and AFt is a mineral with expansive behaviour which significantly damages the microstructure. As a result, the mechanical properties of RMCC decline. When the red mud content is $12 \%$, the cementation effect of CSH gel and the filling effect of AFt have the best coordination indicating the highest ability and stable microstructure of RMCC.

\section{Conclusion}

This paper provides a theoretical guidance to the use of red mud and desulfurization gypsum in subgrade strengthening which exhibits both environmental and economic benefits. Based on these results, the following conclusions are drawn:

(1) The optimum red mud content of RMCC mixture is $12 \%$. With this optimum content, RMCC has the highest strength and the best durability to freezingthawing cycles.

(2) The increase of compressive strength can be divided into two stages, and the strength increases rapidly when the curing period is 14 days. With the increase of the red mud content, the strength and the resistivity of RMCC show the same variation trend, both are first increasing and then decreasing. At the optimum content of red mud, strength and resistivity reach the maximum.

(3) Under freezing-thawing cycle condition, during the first 5 freezing-thawing cycles, the rate of compressive strength loss is faster, and between the 5th and 7 th freezing-thawing cycles, the rate of compressive strength loss slows down. With the progression of the freezing-thawing cycle, the difference of variation in resistivity with different red mud contents decreases. At optimum red mud content, the pressure sensitivity of RMCC gradually reduces with the progression of freezing-thawing cycles.

(4) In the RMCC system, the silicate hydrate contains active $\mathrm{Ca}^{2+}$, which can causes replacement reaction with alkali metal elements playing a key role in the fixation of the alkali metal elements. With the optimum content of red mud, the cementing effect of $\mathrm{CSH}$ gel and the filling effect of AFt are in the best coordination, and the interior pores are the lowest, which results in the highest compressive strength and the best durability to freezing-thawing cycles. The results demonstrate a great potential of RMCC used in subgrade strengthening.

\section{Data Availability}

All the data presented in the manuscript were obtained from laboratory tests at Taiyuan University of Technology in Shanxi China. All the laboratory testing data were presented in the Figures and tables in the manuscript. Additional data can be provided by the corresponding author upon request.

\section{Conflicts of Interest}

The authors declare that they have no conflicts of interest.

\section{Acknowledgments}

This study was supported by the National Natural Science Foundation of China (51978438). 


\section{References}

[1] R. J. Jamshidi and C. B. Lake, "Hydraulic and strength properties of unexposed and freeze-thaw exposed cementstabilized soils," Canadian Geotechnical Journal, vol. 52, no. 3, pp. 283-294, 2015.

[2] B. Ning, S. Chen, B. Liu, and Y. Liu, "Experimental study of cemented soil under environmental erosion," Rock and Soil Mechanics, vol. 26, no. 4, pp. 600-603, 2005.

[3] T. Eskisar, S. Altun, I. Kalipcilar, T. Eskisar, S. Altun, and I. Kalipcilar, "Assessment of strength development and freezethaw performance of cement treated clays at different water contents," Cold Regions Science and Technology, vol. 111, pp. 50-59, 2015.

[4] O. Cuisinier, T. Le Borgne, D. Deneele, and F. Masrouri, "Quantification of the effects of nitrates, phosphates and chlorides on soil stabilization with lime and cement," Engineering Geology, vol. 117, no. 3-4, pp. 229-235, 2011.

[5] G. Feng, T. Qi, X. Du, Z. Wang, and Y. Zhang, "Acoustic emission and ultrasonic characteristics in the failure process of cemented waste concrete-coal gangue backfilling (CWCGB) under uniaxial loading," Advances in Civil Engineering, vol. 2018, Article ID 8960806, 12 pages, 2018.

[6] Z. Li, S. Yan, L. Liu, B. Dai, and W. Dong, "Long-term deformation analysis of recycled construction waste subgrade filler," Advances in Civil Engineering, vol. 2019, Article ID 5891759, 14 pages, 2019.

[7] Y. Huang, J. Chen, S. Shi, B. Li, and Q. Tang, "Mechanical properties of municipal solid waste incinerator (MSWI) bottom ash as alternatives of subgrade materials," Advances in Civil Engineering, vol. 2020, Article ID 9254516, 11 pages, 2020.

[8] R. Zhang, S. Zheng, S. Ma, and Y. Zhang, "Recovery of alumina and alkali in bayer red mud by the formation of andradite-grossular hydrogarnet in hydrothermal process," Journal of Hazardous Materials, vol. 189, no. 3, pp. 827-835, 2011.

[9] W. Liu, X. Chen, W. Li, Y. Yu, and K. Yan, "Environmental assessment, management and utilization of red mud in China," Journal of Cleaner Production, vol. 84, no. 1, pp. 606-610, 2014.

[10] P. Córdoba, "Status of flue gas desulphurisation (FGD) systems from coal-fired power plants: overview of the physicchemical control processes of wet limestone FGDs," Fuel, vol. 144, no. 15, pp. 274-286, 2015.

[11] Y. Kim, Y. Lee, M. Kim, and H. Park, "Preparation of high porosity bricks by utilizing red mud and mine tailing," Journal of Cleaner Production, vol. 207, pp. 490-497, 2019.

[12] W. Xie, F. Zhou, J. Liu et al., "Synergistic reutilization of red mud and spent pot lining for recovering valuable components and stabilizing harmful element," Journal of Cleaner Production, vol. 243, Article ID 118624, 2020.

[13] I. Ghosh, S. Guha, R. Balasubramaniam, and A. V. R. Kumar, "Leaching of metals from fresh and sintered red mud," Journal of Hazardous Materials, vol. 185, no. 2-3, pp. 662-668, 2011.

[14] S. Alam, S. K. Das, and B. H. Rao, "Strength and durability characteristic of alkali activated ggbs stabilized red mud as geo-material," Construction and Building Materials, vol. 211, pp. 932-942, 2019.

[15] N. Zhang, X. Liu, H. Sun, and L. Li, "Evaluation of blends bauxite-calcination-method red mud with other industrial wastes as a cementitious material: properties and hydration characteristics," Journal of Hazardous Materials, vol. 185, no. 1, pp. 329-335, 2011.
[16] E. Mukiza, X. Liu, L. Zhang, and N. Zhang, "Preparation and characterization of a red mud-based road base material: strength formation mechanism and leaching characteristics," Construction and Building Materials, vol. 220, pp. 297-307, 2019.

[17] Q. Wu, H. Ma, Q. Chen, Z. Huang, C. Zhang, and T. Yang, "Preparation of waterproof block by silicate clinker modified FGD gypsum," Construction and Building Materials, vol. 214, pp. 318-325, 2019.

[18] Y. Ma, Q. Nie, R. Xiao et al., "Experimental investigation of utilizing waste flue gas desulfurized gypsum as backfill materials," Construction and Building Materials, vol. 245, Article ID 118393, 2020.

[19] D. Mi, Y. Li, G. Tian, and X. Dong, "Influence of red mud on permeability coefficient of loess solidified by cement," Journal of Guangxi University, vol. 41, no. 4, pp. 1095-1100, 2016.

[20] G. Tian, D. Mi, Y. Lu, and X. Dong, "Effect of different factors on permeability coefficient of loess improved by red mud," Science Technology and Engineering, vol. 17, no. 22, pp. 1671-1815, 2017.

[21] R. Chen, G. Cai, X. Dong, D. Mi, A. J. Puppala, and W. Duan, "Mechanical properties and micro-mechanism of loess roadbed filling using by-product red mud as a partial alternative," Construction and Building Materials, vol. 216, pp. 188-201, 2019.

[22] W. T. Salih, Y. Wang, X. Dong, and H. Wen, "Study on stressstrain-resistivity and microscopic mechanism of red mud waste modified by desulphurization gypsum-fly ash under drying-wetting cycles," Construction and Building Material, vol. 249, Article ID 118772, 2020.

[23] M. Jafari and M. Esna-Ashari, "Effect of waste tire cord reinforcement on unconfined compressive strength of lime stabilized clayey soil under freeze-thaw condition," Cold Regions Science and Technology, vol. 82, pp. 21-29, 2012.

[24] J. Liu, T. Wang, and Y. Tian, "Experimental study of the dynamic properties of cement- and lime-modified clay soils subjected to freeze-thaw cycles," Cold Regions Science and Technology, vol. 61, no. 1, pp. 29-33, 2010.

[25] A. Aldaood, M. Bouasker, and M. Al-Mukhtar, "Impact of freeze-thaw cycles on mechanical behaviour of lime stabilized gypseous soils," Cold Regions Science and Technology, vol. 99, no. 1, pp. 38-45, 2014.

[26] X. Liu, B. Tang, H. Yi, and E. Mukiza, "Durability and environmental performance of bayer red mud-coal ganguebased road base material," Chinese Journal of Engineering, vol. 40, no. 4, pp. 438-445, 2019.

[27] F. Zha, C. Ji, L. Xu, B. Kang, C. Yang, and C. Chu, "Assessment of strength and leaching characteristics of heavy metal-contaminated soils solidified/stabilized by cement/fly ash," Environmental Science and Pollution Research, vol. 26, no. 7, pp. 30206-30219, 2019.

[28] S. H. G. Mosavinejad, A. Ghanizadeh, and J. Barandoust, "Electrode material as a decisive f actor in electrical resistivity measurement of cement composites," Journal of Building Engineering, vol. 25, Article ID 100778, 2019.

[29] X. Dong, N. Su, X. Huang, and X. Bai, "Effect of sewage on electrical resistivity and strength of cemented soil," Rock and Soil Mechanics, vol. 35, no. 7, pp. 1855-1862, 2014.

[30] X. Dong, S. Zhang, B. Yang, and S. Wu, "Application study of electrical resistivity characteristics of core samples from soilcement mixing piles," China Civil Engineering Journal, vol. 49, no. 10 , pp. 88-94, 2016.

[31] X. Dong, F. Huang, N. Su et al., "Experimental study of ac electrical resistivity of unsaturated loss during compression," 
Chinese Journal of Rock Mechanics and Engineering, vol. 34, no. 1, pp. 189-197, 2015.

[32] Z. Wang, Q. Zeng, L. Wang, Y. Yao, and K. Li, "Characterizing blended cement pastes under cyclic freeze-thaw actions by electrical resistivity," Construction and Building Materials, vol. 44, no. 3, pp. 477-486, 2013.

[33] W. Fu and R. Wang, "Experimental study of electrical resistivity and deformation characteristics of saturated silty clay during repeated freeze-thaw cycles," Rock and Soil Mechanics, vol. 31, no. 3, pp. 769-774, 2010.

[34] G. Zhang, J. He, and R. P. Gambrell, "Synthesis, characterization, and mechanical properties of red mud-based geopolymers," Transportation Research Record: Journal of the Transportation Research Board, vol. 2167, no. 1, pp. 1-9, 2010.

[35] China Architecture \& Building Press, Standard for Test Method of Performance on Building Mortar: GJ/T70-2009, China Architecture \& Building Press, Beijing, China, 2008.

[36] China Architecture \& Building Press, Test Methods of LongTerm Performance and Durability of Ordinary Concrete: GB/ T50082-2009, China Architecture \& Building Press, Beijing, China, 2010.

[37] J. Ning and X. Huang, "Effect of mineral component of soil on strength increasing of stabilized soil," Rock and Soil Mechanics, vol. 31, no. 1, pp. 113-117, 2010.

[38] Z. Xiao and Y. Lai, "Study on water and salt transfer mechanism in saline soil under freezing-thawing and dry-wet conditions," Chinese Journal of Rock Mechanics and Engineering, vol. 37, no. 1, pp. 3738-3746, 2018.

[39] S. Paria and P. K. Yuet, "Solidification/stabilization of organic and inorganic contaminants using portland cement: a literature review," Journal of Environmental Reviews, vol. 14, no. 44, pp. 217-255, 2006.

[40] Z. Song, X. Dong, W. Zhou, and Y. F. Chen, "Electrical resistivity-specific parameters of loess grouted with sodium hydroxide," Materials Testing, vol. 59, no. 2, pp. 195-201, 2017.

[41] S. Gao, W. Ni, L. Zhu, Z. Wang, and J. Wang, "Effect of gypsum on strength performance of cemented backfilling materials of red mud-slag system," Journal of Central South University, vol. 44, no. 6, pp. 2259-2266, 2013.

[42] N. H. Koralegedara, P. X. Pinto, D. D. Dionysiou, and S. R. AlAbed, "Recent advances in flue gas desulfurization gypsum processes and applications-a review," Journal of Environmental Management, vol. 251, Article ID 109572, 2019.

[43] F. Cheng, Comparison of Performance of Road Base Materials Made from Red Mud with Different Storage Time and its Strength Mechanism, Huazhong University of Science and Technology, Wuhan, China, 2007.

[44] R. Haynes and Y.-F. Zhou, "Natural ripening with subsequent additions of gypsum and organic matter is key to successful bauxite residue revegetation," Journal of Central South University, vol. 26, no. 2, pp. 289-303, 2019.

[45] G. E. Ho, K. Mathew, and P. W. G. Newman, "Leachate quality from gypsum neutralized red mud applied to sandy soils," Water, Air, and Soil Pollution, vol. 47, no. 1, pp. 1-18, 1989.

[46] S. Wansom, P. Chintasongkro, and W. Srijampan, "Water resistant blended cements containing flue-gas desulfurization gypsum, portland cement and fly ash for structural applications," Cement and Concrete Composites, vol. 103, pp. 134148, 2019.

[47] X.-F. Li, Y. Guo, F. Zhu et al., "Alkalinity stabilization behavior of bauxite residue: $\mathrm{Ca}^{-}$driving regulation characteristics of gypsum," Journal of Central South University, vol. 26, no. 2, pp. 383-392, 2019.

[48] P. Wang and D.-Y. Liu, "Physical and chemical properties of sintering red mud and bayer red mud and the implications for beneficial utilization," Materials, vol. 5, no. 10, pp. 1800-1810, 2012. 